\title{
Chemical Variability in the Composition of Zhumeria majdae (Rech. F. \& Wendelbo) Essential Oil According to Storage Time and Temperature
}

\author{
Akbar Karami ${ }^{1}$ (D) Fatemeh Tashani ${ }^{1}$, Aminallah Tahmasebi ${ }^{2}$ and Filippo Maggi ${ }^{3, *(D)}$ \\ 1 Department of Horticultural Science, School of Agriculture, Shiraz University, Shiraz 71441-65186, Iran; \\ akarami2004@gmail.com (A.K.); ftashani2014@gmail.com (F.T.) \\ 2 Minab Higher Education Center, Department of Agriculture, University of Hormozgan, \\ Bandar Abbas 79161-93145, Iran; Tahmasebi.info@yahoo.com \\ 3 School of Pharmacy, University of Camerino, 62032 Camerino, Italy \\ * Correspondence: filippo.maggi@unicam.it
}

check for updates

Citation: Karami, A.; Tashani, F.; Tahmasebi, A.; Maggi, F. Chemical Variability in the Composition of Zhumeria majdae (Rech. F. \& Wendelbo) Essential Oil According to Storage Time and Temperature. Horticulturae 2021, 7, 463. https:/ / doi.org/10.3390/horticulturae7110463

Academic Editors: Jelena PopovićDjordjević and Luiz Fernando Cappa de Oliveira

Received: 9 September 2021

Accepted: 1 November 2021

Published: 3 November 2021

Publisher's Note: MDPI stays neutral with regard to jurisdictional claims in published maps and institutional affiliations.

Copyright: (c) 2021 by the authors. Licensee MDPI, Basel, Switzerland. This article is an open access article distributed under the terms and conditions of the Creative Commons Attribution (CC BY) license (https:/ / creativecommons.org/licenses/by/ $4.0 /)$.
Abstract: Zhumeria majdae (Rech. F. \& Wendelbo) is an aromatic herb belonging to the Lamiaceae family, traditionally employed in the Persian medicine for the treatment of a wide number of diseases. In the present study, the chemical composition of Z. majdae essential oil obtained from the plant's aerial features, and stored at various temperatures (refrigerator temperature $4{ }^{\circ} \mathrm{C}$, freezer temperature $-20{ }^{\circ} \mathrm{C}$, and room temperature $\left.20 \pm 3{ }^{\circ} \mathrm{C}\right)$ and times $(0,3,6$, and 9 months) was studied. The essential oil was isolated through hydrodistillation, and its composition was evaluated by gas chromatography/mass spectrometry (GC/MS). The results showed that the composition of essential oils changed as a function of the various storage temperatures and times. Linalool (34.85-48.45\%), camphor (27.09-39.17\%), limonene (1.97-4.88\%), and camphene (1.6-4.84\%) made up the main volatile compounds which showed differences in their concentrations according to the various storage conditions. Notably, when compared to a non-stored treatment sample (analyzed immediately after essential oil collection), the amount of linalool and camphor increased in all samples stored in all conditions of temperature and time, with the exception of the samples stored for nine months at room temperature. On the other hand, limonene and camphene contents decreased during the storage treatments, showing that the highest content of these compounds occurred in the non-stored treatment. Essential oil storage at the freezer temperature and for three months storage time resulted in the highest average value of the major constituents, highlighting these as the best conditions for obtaining the highest content of the major compounds.

Keywords: chemical constituents; essential oil; storage temperature; storage time; Zhumeria majdae

\section{Introduction}

Essential oils produced by aromatic plants are made up of various phytochemical combinations, including hydrocarbons, monoterpenes, sesquiterpenes, and phenylpropanoids [1]. Zhumeria majdae (Rech. F. \& Wendelbo) (Lamiaceae family) is an aromatic herb that grows wild in Hormozgan Province, southern Iran [2,3]. Its aerial parts are used in Iranian traditional medicine to cure dysmenorrhea, stomachache, acid reflux, cold, headache, diarrhea, wounds, and indigestion [4-7]. A few pharmacological properties have been evidenced for the Z. majdae extracts, namely anti-nociceptive and anti-inflammatory properties [2]. It has been previously shown that linalool, camphor, and limonene constitute the major Z. majdae essential oil components [8-11]. This essential oil has been proven to exhibit insecticidal, antioxidant, antifungal, and antibacterial properties [9,11-16]. A recent study showed that Z. majdae has also an effective on morphine withdrawal syndrome in mice [8].

Essential oils are recognized as valuable products worthy of industrial exploitation, since they show a wide range of biological properties including antimicrobial, antidiabetic, 
repellent, anticancer, antioxidant, and anti-inflammatory [17-21]. Thus, they are extensively used in the food, pharmaceutical, cosmetics, and perfume industries [1,22-26]. Notably, there is a growing interest in the use of plant essential oils as natural substitutes for synthetic compounds in human health [27].

The storage process of essential oil is considered a pivotal step in conserving the product quality [28]. On the other hand, the chemical composition of essential oils can be affected by a number of factors, including environmental conditions, collection time, phenological stages, and extraction methods [29-33]. Moreover, it has been shown that some environmental factors, including light, temperature, and oxygen availability, change the composition of essential oils during the storage process [34]. Instability and degradation of essential oils are caused by environmental factors during storage conditions [28]. Temperature is one of the most important factors affecting the quality of essential oils [35-38]. Little is known in terms of the effect of storage conditions on the chemical composition of $Z$. majdae essential oil. Therefore, the present study was conducted to evaluate the effect of various storage factors, including temperature and time durations, on Z. majdae essential oil composition during 9 months of storage at various temperatures, which may represent the best storage conditions to obtain high quality essential oil.

\section{Materials and Methods}

\subsection{Plant Material and Essential Oil Isolation Procedure}

The aerial features of $Z$. majdae were collected at the flowering stage from the Geno mountains, Hormozgan Province, southern Iran $\left(27^{\circ} 23^{\prime} 10^{\prime \prime}\right.$ N latitude, $56^{\circ} 11^{\prime} 55^{\prime \prime}$ E longitude), in March 2018. For plant collection, the aerial parts of five plants in three replications were harvested from the natural habitat; the distance between each replication was approximately $50 \mathrm{~m}$. The aerial parts were air-dried at ambient temperature. The Z. majdae essential oil was obtained through hydrodistillation for $3 \mathrm{~h}$ in three replications, using a Clevenger apparatus. The essential oil was separated, dried with anhydrous sodium sulfate, and kept in closed dark vials.

\subsection{Essential Oil Storage Conditions}

Z. majdae essential oil composition was investigated using various storage temperatures and times through the methods as described previously $[35,36,38]$. In this regard, the effect of three storage temperatures, namely room temperature $\left(20 \pm 3^{\circ} \mathrm{C}\right)$, refrigerator $\left(4{ }^{\circ} \mathrm{C}\right)$, and freezer temperature $\left(-20^{\circ} \mathrm{C}\right)$ and four storage time levels (non-stored: this sample was analyzed immediately after its collection from the Clevenger apparatus; three months; six months; and nine months) on the chemical composition was evaluated. The essential oil samples were stored in closed dark vials, and the essential oil composition of each treatment was assessed by gas chromatography/mass spectrometry (GC/MS).

\subsection{Essential Oil Analysis}

The essential oil compounds were identified using a gas chromatograph (Model 7890A, Agilent Technologies, Wilmington, DE, USA) containing a flame ionization detector (FID) and an HP-5 column ( $30 \mathrm{~mL} \times 0.25 \mathrm{~mm}$ i.d., $0.25 \mu \mathrm{m}$ f.t.). The temperature program of the column began at $60^{\circ} \mathrm{C}$, increased to $210{ }^{\circ} \mathrm{C}$ at $3{ }^{\circ} \mathrm{C} / \mathrm{min}$, and then reached $240{ }^{\circ} \mathrm{C}$ at $20{ }^{\circ} \mathrm{C} / \mathrm{min}$; the program continued for $8.5 \mathrm{~min}$ at $240{ }^{\circ} \mathrm{C}$. The temperature of the injector was $280^{\circ} \mathrm{C}$. Nitrogen was the carrier gas, with a flow rate of $1 \mathrm{~mL} / \mathrm{min}$. GC/MS analysis was conducted by the GC connected to a mass-spectrometer (Model MS5975C, Agilent Technologies, Wilmington, DE, USA). The stationary phase was a HP-5MS $(30 \mathrm{~mL} \times 0.32 \mathrm{~mm}$ i.d., $0.25 \mu \mathrm{m}$ f.t.). The temperature of the MS injector and detector was $280^{\circ} \mathrm{C}$. The carrier gas was applied at a $1 \mathrm{~mL} / \mathrm{min}$ flow rate. The ionization energy used here was equal to $70 \mathrm{eV}$. The gas chromatography/flame ionization detection (GC-FID) semi-quantitative determination of each essential oil component was based on the peak area normalization without using response factors. 


\subsection{Correlation, Principal Component, Cluster and Statistical Analyses}

Pearson correlation analysis was performed in order to evaluate the relationship between the major essential oil compounds (linalool, camphor, limonene, and camphene) using SPSS software version 21 (SPSS Inc., Chicago, IL, USA). Moreover, principal component analysis of the major essential oil compounds during the various storage conditions and cluster analysis of the storage times ( $0,3,6$, and 9 months) were conducted using Minitab 16 statistical software. Data were analyzed as a completely randomized design with three replications. Data were expressed as means \pm standard deviation (SD). The statistical significance of differences between treatments were determined by analysis of variance (ANOVA), and testing for differences between means were measured by the least significant difference (LSD) test at $p \leq 0.05$.

\section{Results and Discussion}

In this study, the essential oil composition of Z. majdae was assessed at different temperatures and storage times. The harvesting and storage are important factors affecting the essential oil quality and chemical profile [39,40]. It has also been shown that the increase of temperature during storage decreases product quality [41-43]. Therefore, in this study, we evaluated the effect of various storage conditions, including temperature and storage times, on the composition of Z. majdae essential oil. A number of previous studies highlighted the influence of different storage conditions on the overall essential oil profile $[35,36,38,44,45]$. The results showed that the quali-quantitative composition of $Z$. majdae essential oil changed as a function of the various temperatures and storage times (Table 1). GC-FID and GC/MS analyses revealed four main volatile constituents, namely linalool (34.85-48.45\%), camphor (27.09-39.17\%), limonene (1.97-4.88\%), and camphene (1.6-4.84\%), with fluctuations in composition percentages according to the storage conditions applied (Table 1). Compared to the non-stored sample, linalool and camphor increased in all of the storage treatments with the exception of the sample analyzed after nine months at room temperature. Linalool showed the highest increment at three- and nine-months storage at $4{ }^{\circ} \mathrm{C}$ (i.e., 22.89 , and $22.94 \%$, respectively) (Figure 1). In addition, camphor exhibited the highest increment $(26.60 \%)$ at three months storage at $4{ }^{\circ} \mathrm{C}$, when compared to the non-stored sample (Figure 2). The highest concentrations of linalool and camphor were obtained at three months storage. On the other hand, the greatest decrease for linalool and camphor was detected after 9 months at room temperature (11.57 and $12.44 \%$, respectively). With regard to limonene and camphene, they decreased during all storage treatments, compared to non-stored sample (Figures 3 and 4). Notably, limonene showed the greatest reduction at three- and nine-months storage at $4{ }^{\circ} \mathrm{C}(59.63 \%$ decreased rate) (Figure 3), whereas camphene revealed the highest decline rate during three- and nine-months storage at $4{ }^{\circ} \mathrm{C}$ (66.94 and $65.29 \%$, respectively) (Figure 4$)$. It has been shown that some environmental factors, including temperature, light, and oxygen availability, change essential oil composition during the storage periods $[35,36,38]$. Temperature is one of the most important factors affecting the quality of essential oils [35-38]. In this study, the major components of $Z$. majdae were affected by the temperature of the storage conditions. In the previous study, the major constituents of balm mint (Melissa officinalis L.) essential oil, including citronellal, neral, and geranial, were decreased in storage conditions, and the highest and lowest reductions occurred at room and freezer temperatures, respectively [36]. The molecular weights of linalool (154.25) and camphor (152.23) are higher than those of limonene (136.23) and camphene (136.23). The findings of our results indicated that the content of compounds with a lower molecular weight decreased by prolonging the storage time, especially at room temperature. Previous research shows that the evaporation, oxidation, and other unwanted changes in essential oil components during the storage period could be related to molecular weights of compounds [45]. 
Table 1. Chemical composition of the essential oil Zhumeria majdae at various storage times and temperatures.

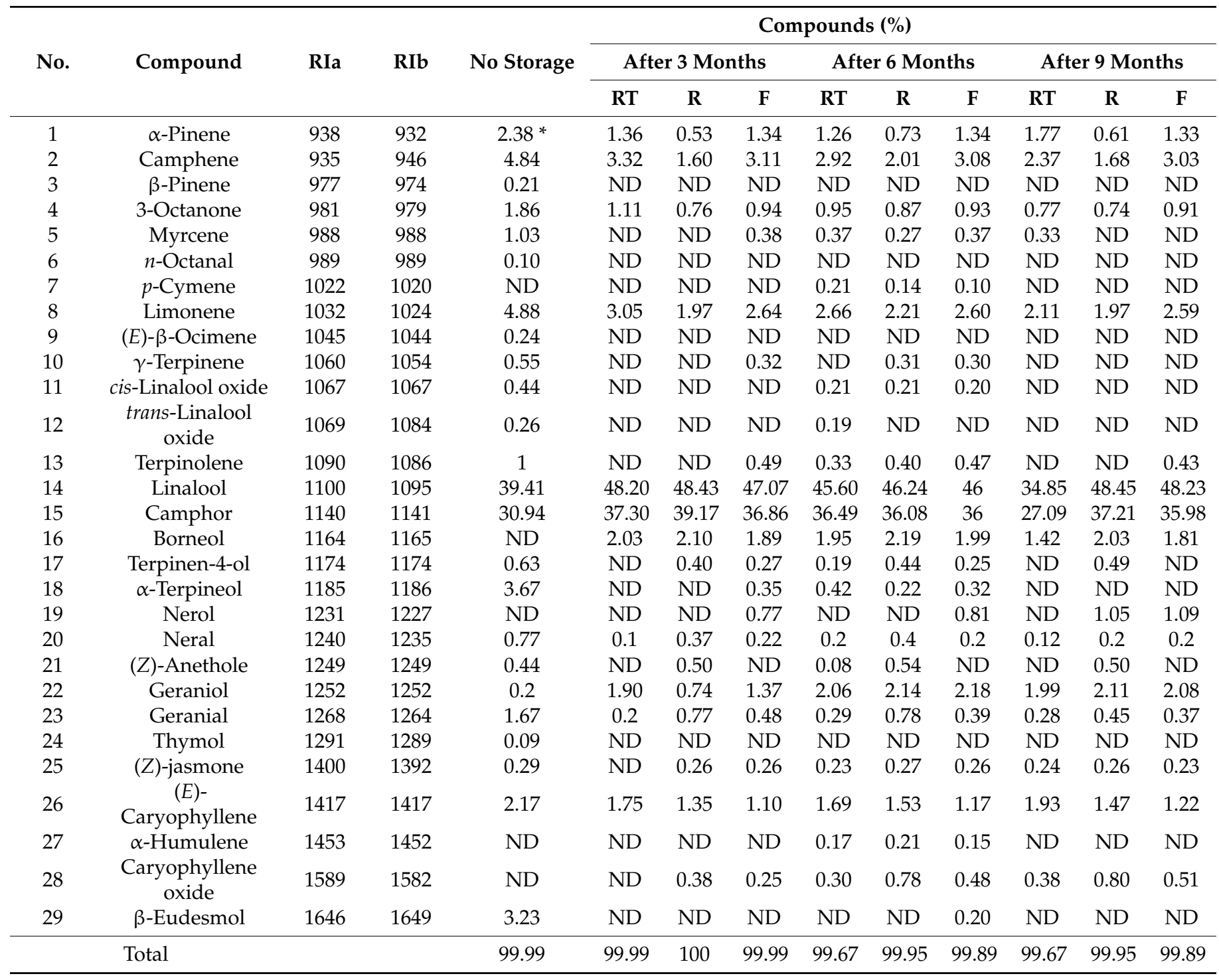

RIa: Retention indices analyses on HP-5MS column; RIb: Retention index value taken from ADAMS library; ND: not detected; RT: Room Temperature; R: Refrigerator Temperature; F: Freezer Temperature. * Data of this table is the mean of three replicated analyzed samples. 


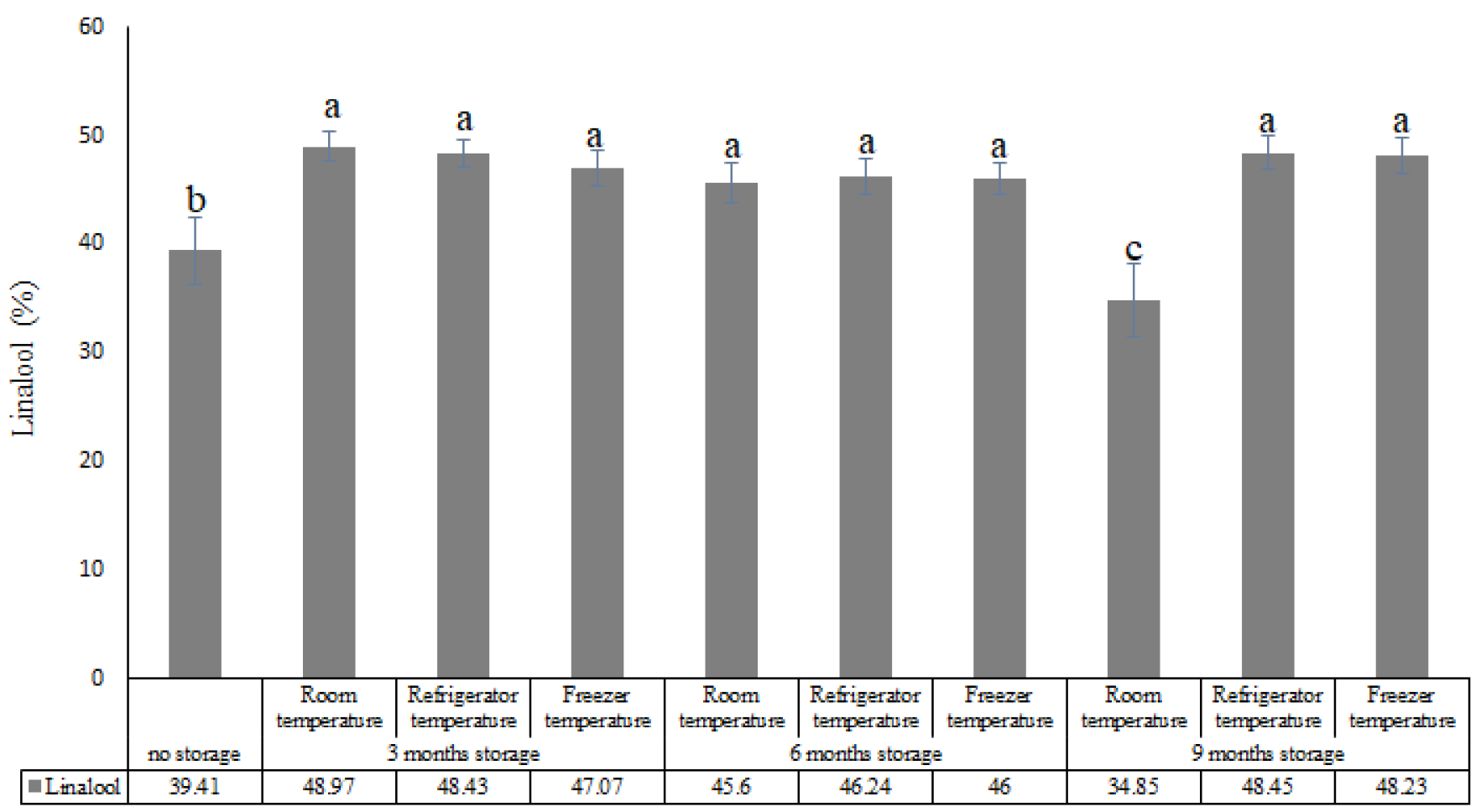

Figure 1. The linalool content of Zhumeria majdae essential oil at various storage times and temperatures; the different letters denote a statistically significant difference at $p \leq 0.05$, as determined by LSD tests.

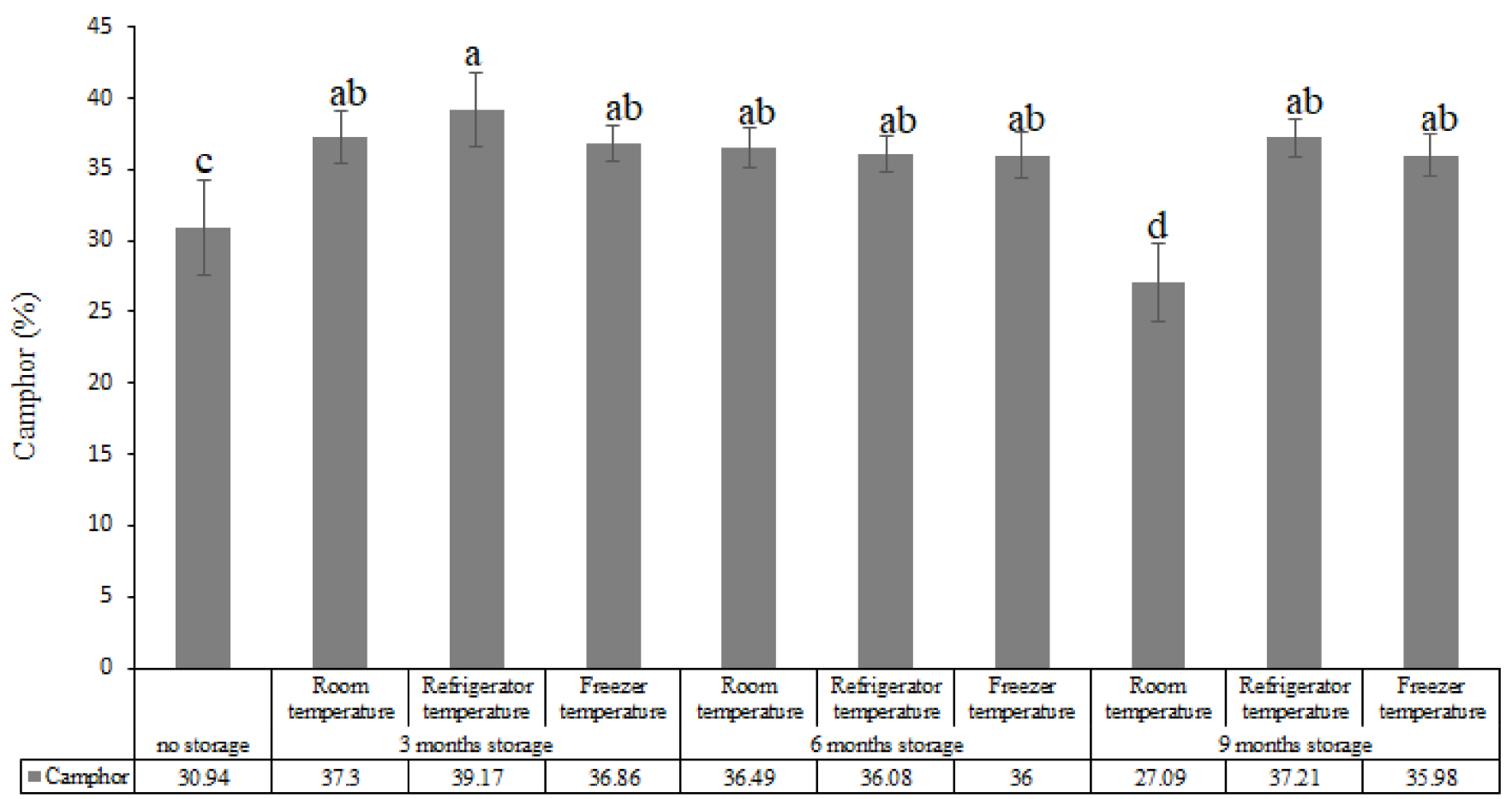

Figure 2. The camphor content of Zhumeria majdae essential oil at various storage times and temperatures; the different letters denote a statistically significant difference at $p \leq 0.05$, as determined by LSD tests. 


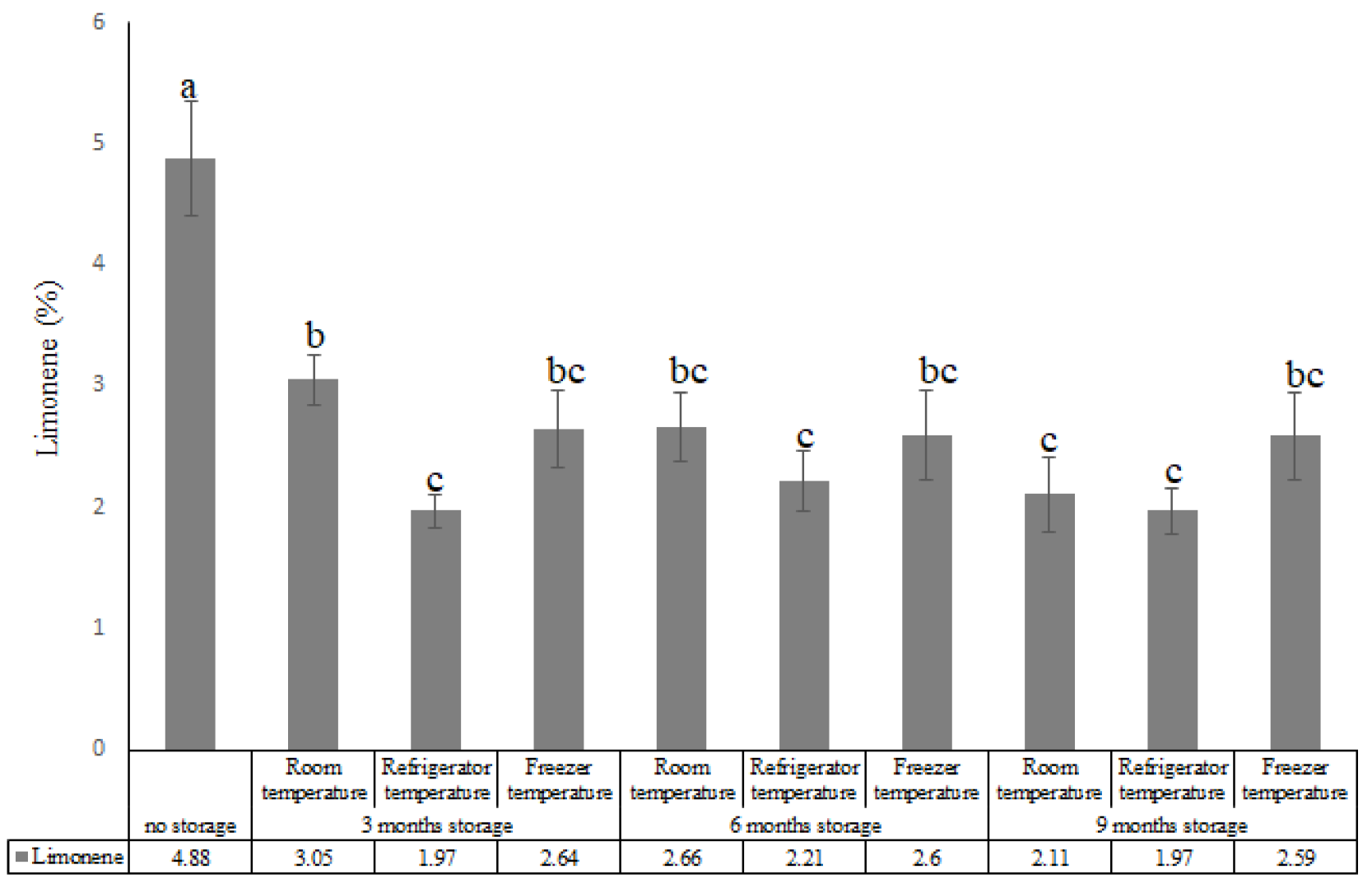

Figure 3. The limonene content of Zhumeria majdae essential oil at various storage times and temperatures; the different letters denote a statistically significant difference at $p \leq 0.05$, as determined by LSD tests.

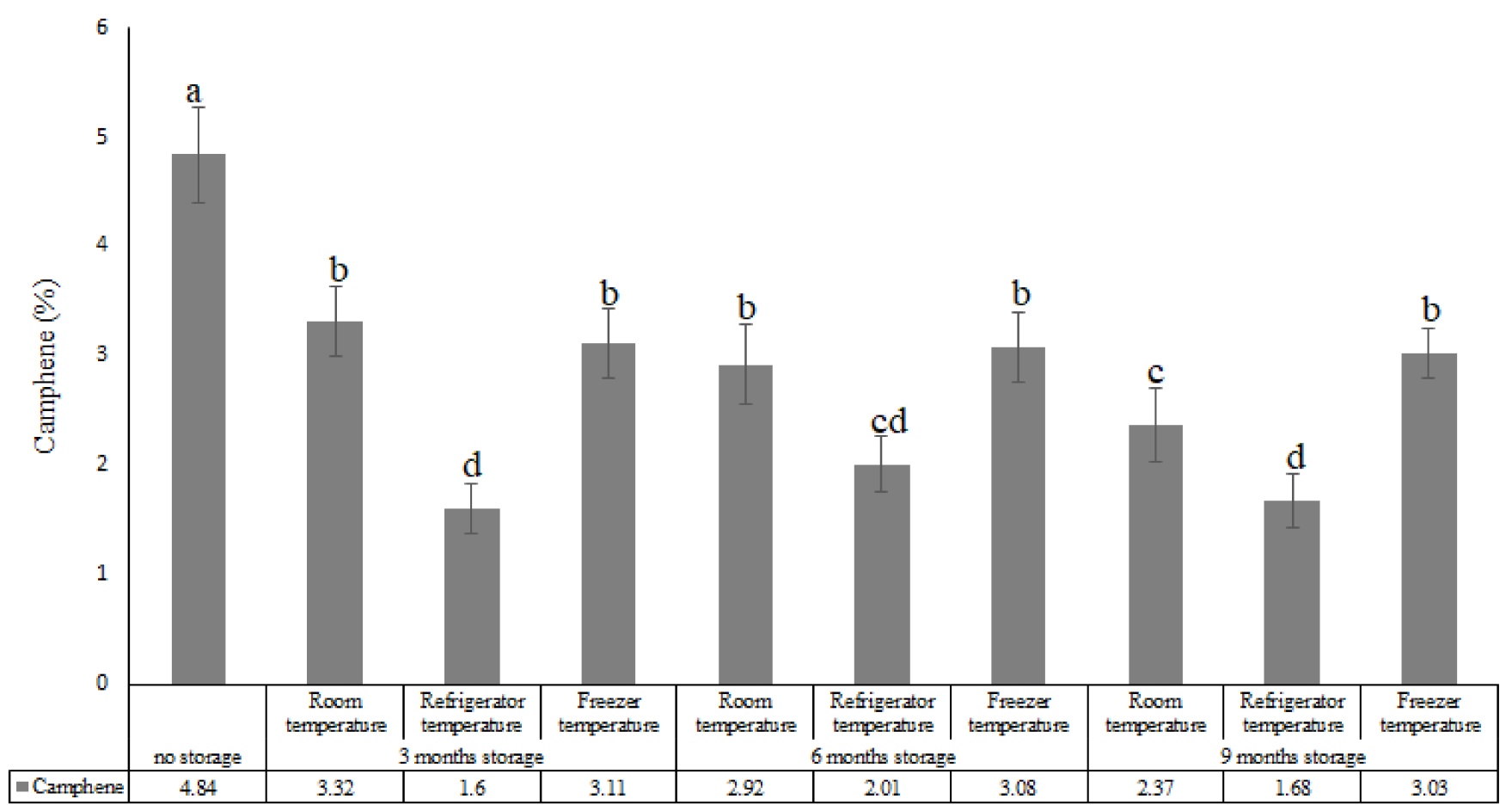

Figure 4. The camphene content of Zhumeria majdae essential oil at various storage times and temperatures; the different letters denote a statistically significant difference at $p \leq 0.05$, as determined by LSD tests.

Other compounds including $\alpha$-pinene, 3-octanone, myrcene, $\gamma$-terpinene, terpinolene, terpinen-4-ol, $\alpha$-terpineol, geranial, isophorone, cis-jasmone, (E)-caryophyllene, and neral, 
revealed a higher content in the non-stored sample (Table 1). Notably, some constituents were specifically identified in samples analyzed with particular storage treatments. In this regard, $\beta$-pinene, $n$-octanal, $(E)$ - $\beta$-ocimene, and thymol were found only in the non-stored sample. Moreover, cis-linalool oxide, trans-linalool oxide and $\beta$-eudesmol were found in the non-stored and six-month storage samples (Table 1). $p$-Cymene and $\alpha$-humulene were detected in the six-month storage sample (Table 1). However, a variety of compounds, including borneol, nerol, geraniol, and caryophyllene oxide, were not found in the nonstored sample (Table 1). Moreover, $\alpha$-terpineol, 2,6-octadiene, and neral were not found in the nine-month storage sample (Table 1).

The findings also revealed that, when compared to refrigerator and room temperatures, essential oil storage at the freezer temperature resulted in the most average value of the major constituents, which may be due to the protection of antioxidant compounds of the essential oil at this temperature. In addition, storage treatments decreased the number of compounds present. Indeed, a total of 25 constituents were found in the non-stored essential oil sample in the highest amount (Table 1). Compared to three- and nine-month storage samples, the number of compounds increased in the six-month storage sample. The changes in the content and number of the essential oil compounds could be attributed to a number of factors, including evaporation and oxidation during the storage period [36]. Moreover, essential oils might be transformed to other phytochemical constituents through a number of chemical reactions, including isomerization, dehydrogenation, and cyclization $[36,46]$. Therefore, less stable compounds quickly degrade due to their chemical interactions with other constituents [47], occurring as a function of storage times and temperatures.

Pearson correlation analysis exhibited a significant positive correlation between linalool and camphor $(r=0.986$, significant at the 0.05 level) (Table 2). In addition, camphene showed a significant positive correlation with limonene content $(r=1$, significant at the 0.01 level) (Table 2). On the other hand, limonene had a non-significant negative correlation with linalool and camphor $(\mathrm{r}=-0.824$ and -0.731 , respectively) (Table 2). Camphene revealed a non-significant negative correlation with linalool and camphor $(\mathrm{r}=-0.820$ and -0.725 , respectively) (Table 2$)$. Therefore, the correlation findings highlighted that increases in linalool and camphor were associated with a decrease in camphene and limonene contents. Principal component analysis was performed based on the major Z. majdae essential oil compounds (i.e., linalool, camphor, limonene, and camphene) under the various storage conditions (Figure 5). The findings showed that essential oils stored under various storage conditions were placed into three different groups: three-, six-, and nine-months storage, and non-stored samples (Figure 5). In addition, the essential oil sample which underwent no storage treatment was placed close to limonene and camphene, showing the highest content of these compounds in the non-stored group. Meanwhile, the essential oil kept for three months was placed close to linalool and camphor, highlighting the highest concentration of linalool and camphor at three months storage (Figure 5). Furthermore, the hierarchical cluster analysis of the Z. majdae essential oils during the different storage times showed various degrees of similarity among the storage times (Figure 6). In this respect, the cluster analysis revealed that the similarity of essential oil storage times ranged from 24.29 to $74.76 \%$ (Figure 6). The non-stored sample demonstrated the lowest similarity $(24.29 \%)$ in the major essential oil compounds, compared with other storage times. Moreover, three- and six-month storage times showed the highest similarity $(74.76 \%)$ in the major essential oil compounds. The treatments, namely three-, six-, and nine-months storage times, represented a 36.91\% similarity level (Figure 6). 
Table 2. The Pearson correlation coefficient between the major essential oil components of Zhumeria majdae at various storage times and temperatures.

\begin{tabular}{ccccc}
\hline & Linalool & Camphor & Limonene & Camphene \\
\hline Linalool & 1 & & & \\
Camphor & $0.986^{*}$ & 1 & & \\
Limonene & $-0.824 \mathrm{~ns}$ & $-0.731 \mathrm{~ns}$ & 1 & 1 \\
Camphene & $-0.820 \mathrm{~ns}$ & $-0.725 \mathrm{~ns}$ & $1^{* *}$ & 1 \\
\hline
\end{tabular}

$\mathrm{ns}^{*}{ }^{*}$ and ${ }^{* *}$ represent no significant and significant correlation at the 0.05 and 0.01 levels (two-tailed), respectively.

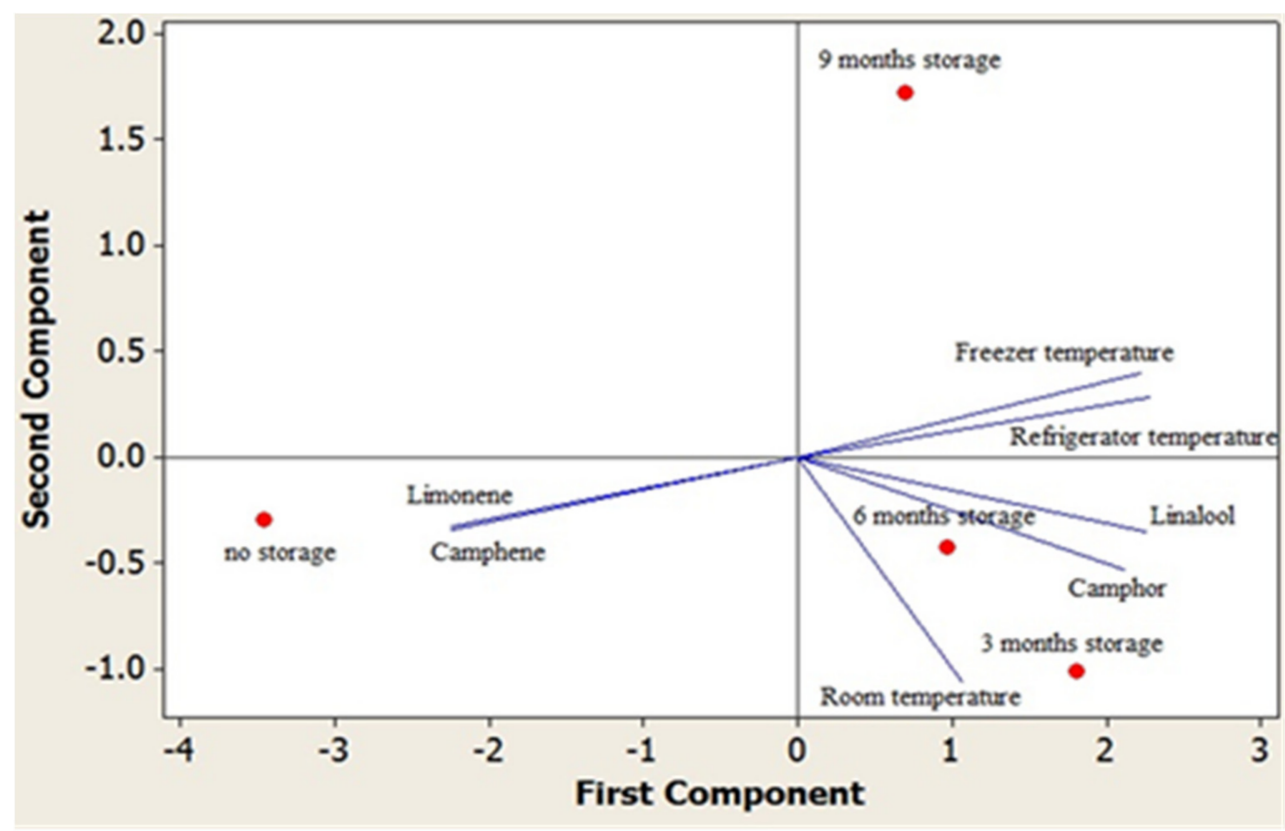

Figure 5. Biplot of the first two principal components for the major Zhumeria majdae essential compounds (linalool, camphor, limonene, and camphene) at various temperatures and storage times.

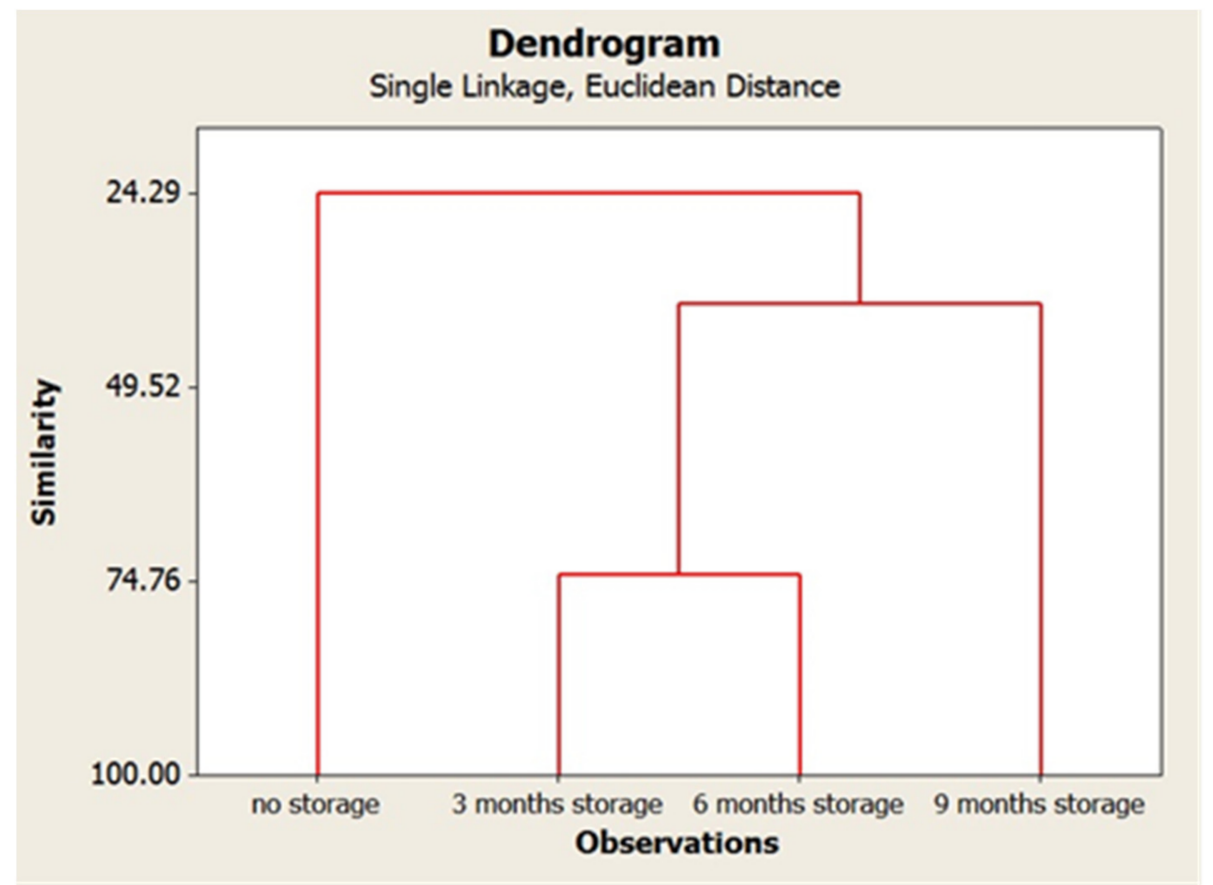

Figure 6. Hierarchical cluster analysis of the major Zhumeria majdae essential compounds (linalool, camphor, limonene, and camphene) at various temperatures and storage times. 


\section{Conclusions}

In the present work, we studied the variation in the major constituents of Z. majdae essential oil as affected by storage conditions. The results showed that, compared to the non-stored sample, linalool and camphor increased under all the storage treatments, with the exception of the sample analyzed after nine months at room temperature. With regard to limonene and camphene, they decreased during all storage treatments, compared to the non-stored sample; however, this reduction was very low under freezer storage conditions, as compared to refrigerator temperature. Thus, the essential oil stored in the freezer contained higher amounts of limonene and camphene, which may have prevented their contents decreasing after nine months. Therefore, the information generated here may aid the food, cosmetic, and pharmaceutical industries to be aware of the effect of storage conditions on Z. majdae essential oil quality, and its storage at the most appropriate conditions.

Author Contributions: Conceptualization, A.K. and F.M.; methodology, F.T.; software, A.T.; validation, A.K., F.M. and A.T.; formal analysis, F.T.; investigation, F.T.; resources, A.K.; data curation, A.K.; writing—original draft preparation, A.T.; writing—review and editing, A.K. and F.M.; supervision, A.K.; funding acquisition, A.K. and F.M. All authors have read and agreed to the published version of the manuscript.

Funding: This research was funded by Shiraz University (grant number 98GCU1M154198), and the APC was funded by F.M.

Conflicts of Interest: The authors declare no conflict of interest.

\section{References}

1. Omidbaigi, R. Production and Processing of Medicinal Plants 1; Behnashr Press: Khorasan Razavi, Iran, 2005 ; p. 347.

2. Hosseinzadeh, H.; Ramezani, M.; Fadishei, M.; Mahmoudi, M. Antinociceptive, anti-inflammatory and acute toxicity effects of Zhumeria majdae extracts in mice and rats. Phytomedicine 2002, 9, 135-141. [CrossRef]

3. Sharififar, F.; Mozaffarian, V.; Moshafi, M.H.; Dehghan-Nudeh, G.; Parandeh-Rezvani, J.; Mahdavi, Z. Chemical composition and biological activities of Zhumeria majdae Resh. F. \& wendelbo. Jundishapur J. Nat. Pharm. Prod. 2008, 3, 8-18.

4. Zargari, A. Medicinal Plants; Tehran University Publications: Tehran, Iran, 1995.

5. Izaddoost, M.; Rustaiyan, A.; Niknejad, A. Phytochemical Study of Zhumeria majdae; Biochemical Society Transactions: London, UK, 1983; pp. 1023-1027.

6. Moein, S.; Moein, M.R. Relationship between antioxidant properties and phenolics in Zhumeria Majdae. J. Med. Plants Res. 2010, 4, 517-521.

7. Naghibi, F.; Mosadegh, M.; Mohammadi, M.S.; Ghorbani, A.B. Labiatae family in folk medicine in Iran: From ethnobotany to pharmacology. Iran. J. Pharm. Res. 2010, 4, 63-79.

8. Ehtemami, Z.; Shafaroodi, H.; Asgarpanah, J. Effect of essential oil of Zhumeria majdae on morphine tolerance and dependence in mice. Chin. J. Integr. Med. 2020, 26, 683-687. [CrossRef]

9. Arman, M.; Yousefzadi, M.; Ebrahimi, S.N. Antimicrobial activity and composition of the essential oil from Zhumeria majdae Rech. f. \& Wendelbo. J. Essent. Oil Bear. Plants 2009, 12, 630-634.

10. Fallah, M.; Farzaneh, M.; Yousefzadi, M.; Ghorbanpour, M.; Mirjalili, M.H. In vitro mass propagation and conservation of a rare medicinal plant, Zhumeria majdae Rech. f \& Wendelbo (Lamiaceae). Biocatal. Agric. Biotechnol. 2019, 17, 318-325.

11. Mirzakhani, M.; Ekrami, M.; Moini, S. Chemical composition, total phenolic content and antimicrobial activities of Zhumeria majdae. J. Food Bioprocess Eng. 2018, 2, 1-8.

12. Sanei-Dehkordi, A.; Soleimani-Ahmadi, M.; Akbarzadeh, K.; Salim Abadi, Y.; Paksa, A.; Gorouhi, M.A.; Mohammadi-Azni, S. Chemical composition and mosquito larvicidal properties of essential oil from leaves of an Iranian indigenous plant Zhumeria Majdae. J. Essent. Oil Bear. Plants 2016, 19, 1454-1461. [CrossRef]

13. Ebadollahi, A.; Khosravi, R.; Sendi, J.; Mahboubi, M.; Kosari, A.A. Chemical composition of essential oil from Zhumeria majdae Rech. F. \& Wendelbo and its bioactivities against Tribolium castaneum Herbst (Tenebrionidae) larvae. J. Essent. Oil Bear. Plants 2014, 17, 824-831.

14. Omidpanah, N.; Valifard, M.; Esmaeili, M.; Yousefi, R.; Moghadam, A. Antioxidant and antibacterial properties of the essential oils of two Iranian Medicinal Plants: Zhumeria majdae and Salvia mirzayanii. J. Adv. Med. Sci. Appl. Technol. 2015, 1, 51-60. [CrossRef]

15. Imani, Z.; Asgarpanah, J.; Hashemi, F.; Hezaveh, J.H. Composition and antifungal activity of Zhumeria majdae essential oil. Curr. Med. Mycol. 2015, 1, 13. [CrossRef] [PubMed]

16. Emami, R.; Ghaneian, M.R.; Jebali, J. Antimicrobial activity and toxicity of Zhumeria majdae essential oil and its capsulated form. J. Community Health Res. 2015, 3, 242-252. 
17. Buchbauer, G. Biological activities of essential oils. In Handbook of Essential Oils: Science, Technology, and Applications; Baser, K.H.C., Buchbauer, G., Eds.; CRC Press: Boca Raton, FL, USA, 2010; pp. 235-280.

18. Teixeira, B.; Marques, A.; Ramos, C.; Neng, N.R.; Nogueira, M.R.; Saraiva, J.R.; Nunes, M.L. Chemical composition and antibacterial and antioxidant properties of commercial essential oils. Ind. Crop. Prod. 2013, 43, 587-595. [CrossRef]

19. Raut, J.S.; Karuppayil, S.M. A status review on the medicinal properties of essential oils. Ind. Crop. Prod. 2014, 62, 250-264. [CrossRef]

20. Said, Z.B.O.S.; Haddadi-Guemghar, H.; Boulekbache-Makhlouf, L.; Rigou, P.; Remini, H.; Adjaoud, A.; Khoudja, N.K.; Madani, K. Essential oils composition, antibacterial and antioxidant activities of hydrodistillated extract of Eucalyptus globulus fruits. Ind. Crop. Prod. 2016, 89, 167-175. [CrossRef]

21. Swamy, M.K.; Sinniah, U.R.; Akhtar, M.S. Antimicrobial properties of plant essential oils against human pathogens and their mode of action: An updated review. Evid.-Based Complement. Altern. Med. 2016, 2016, 3012462. [CrossRef]

22. Bakkali, F.; Averbeck, S.; Averbeck, D.; Idaomar, M. Biological effects of essential oils-A review. Food Chem. Toxicol. 2008, 46, 446-475. [CrossRef]

23. Silva, J.; Abebe, W.; Sousa, S.M.; Duarte, V.G.; Machado, M.I.L.; Matos, F.J.A. Analgesic and anti-inflammatory effects of essential oils of Eucalyptus. J. Ethnopharmacol. 2003, 89, 277-283. [CrossRef]

24. Hajhashemi, V.; Ghannadi, A.; Sharif, B. Anti-inflammatory and analgesic properties of the leaf extracts and essential oil of Lavandula angustifolia Mill. J. Ethnopharmacol. 2003, 89, 67-71. [CrossRef]

25. Perry, N.S.; Bollen, C.; Perry, E.K.; Ballard, C. Salvia for dementia therapy: Review of pharmacological activity and pilot tolerability clinical trial. Pharmacol. Biochem. Behav. 2003, 75, 651-659. [CrossRef]

26. Nychas, G.H.; Tassou, C.C.; Skandamis, P. Antimicrobials from herbs and spices. In Natural Antimicrobials for the Minimal Processing of Foods; Roller, S.M., Ed.; Wood Head Publishers: New York, NY, USA, 2003; pp. 176-200.

27. Nieto, G. Biological activities of three essential oils of the Lamiaceae family. Medicines 2017, 4, 63. [CrossRef]

28. Jesus, A.S.D.; Blank, A.F.; Alves, M.F.; Arrigoni-Blank, M.D.F.; Lima, R.N.; Alves, P.B. Influence of storage time and temperature on the chemical composition of the essential oil of Hyptis pectinata L. Poit. Rev. Bras. Plantas Med. 2016, 18, 336-340. [CrossRef]

29. Moghaddam, M.; Omidbaigi, R.; Sefidkon, F. Changes in content and chemical composition of Tagetes minuta oil at various harvest times. J. Essent. Oil Res. 2007, 19, 18-20. [CrossRef]

30. Figueiredo, A.C.; Barroso, J.G.; Pedro, L.G.; Scheffer, J.J. Factors affecting secondary metabolite production in plants: Volatile components and essential oils. Flavour Fragr. J. 2008, 23, 213-226. [CrossRef]

31. Demuner, A.J.; Almeida Barbosa, L.C.; Gonçalves Magalhaes, C.; Da Silva, C.J.; Alvares Maltha, C.R.; Lelis Pinheiro, A. Seasonal variation in the chemical composition and antimicrobial activity of volatile oils of three species of Leptospermum (Myrtaceae) grown in Brazil. Molecules 2011, 16, 1181-1191. [CrossRef] [PubMed]

32. Tahmasebi, A.; Hosseini, S.M.; Karami, A.; Afsharifar, A.; Sharifi Olounabadi, A.R. Variation in essential oil composition of Rydingia michauxii at the three developmental stages. Nat. Prod. Res. 2021, 35, 342-345. [CrossRef] [PubMed]

33. Moghaddam, M.; Ghasemi Pirbalouti, A.; Mehdizadeh, L.; Pirmoradi, M.R. Changes in composition and essential oil yield of Ocimum ciliatum at different phenological stages. Eur. Food Res. Technol. 2015, 240, 199-204. [CrossRef]

34. Nguyen, H.; Campi, E.M.; Jackson, W.R.; Patti, A.F. Effect of oxidative deterioration on flavor and aroma components of Lemon oil. Food Chem. 2009, 112, 388-393. [CrossRef]

35. Mohtashami, S.; Rowshan, V.; Tabrizi, L.; Babalar, M.; Ghani, A. Summer savory (Satureja hortensis L.) essential oil constituent oscillation at different storage conditions. Ind. Crop. Prod. 2018, 111, 226-231. [CrossRef]

36. Najafian, S. Storage conditions affect the essential oil composition of cultivated balm mint herb (Lamiaceae) in Iran. Ind. Crop. Prod. 2014, 52, 575-581. [CrossRef]

37. Mehdizadeh, L.; Ghasemi Pirbalouti, A.; Moghaddam, M. Storage stability of essential oil of cumin (Cuminum cyminum L.) as a function of temperature. Int. J. Food Prop. 2017, 20, 1742-1750. [CrossRef]

38. Rowshan, V.; Bahmanzadehgan, A.; Saharkhiz, M.J. Influence of storage conditions on the essential oil composition of Thymus daenensis Celak. Ind. Crop. Prod. 2013, 49, 97-101. [CrossRef]

39. Ehlert, P.A.D.; Ming, L.C.; Marques, M.O.M.; Fenandes, D.M.; Rocha, W.A.; Luz, J.M.Q.; Silva, R.F. Influência do horário de colheita sobre o rendimento e composição do óleo essencial de erva-cidreira brasileira [Lippia alba (Mill.) NE Br.]. Rev. Bras. Plantas Med. 2013, 15, 72-77. [CrossRef]

40. Silva, F.; Park, K.J.; Magalhães, P.M.; Martins, G.N.; Gama, E.V.S. Avaliação do teor de óleo essencial de Baccharis trimera (Less.) DC. em diferentes embalagens durante o armazenamento. Rev. Bras. Plantas Med. 2013, 15, 54-58. [CrossRef]

41. Jacxsens, L.; Devlieghere, F.; Debevere, J. Temperature dependence of shelf life as affected by microbial proliferation and sensory quality of equilibrium modified atmosphere packaged fresh produce. Postharvest Biol. Technol. 2002, 26, 59-73. [CrossRef]

42. Ding, C.K.; Chachin, K.; Yasunori, H.; Yasunori, U.; Yasunori, I. Effects of storage temperatures on physiology and quality of loquat fruit. Postharvest Biol. Technol. 1998, 14, 309-315. [CrossRef]

43. Maalekuu, K.; Elkind, Y.; Leikin-Frenkel, A.; Lurie, S.; Fallik, E. The relationship between water loss, lipid content, membrane integrity and LOX activity in ripe pepper fruit after storage. Postharvest Biol. Technol. 2006, 42, 248-255. [CrossRef]

44. Turek, C.; Stintzing, F.C. Impact of different storage conditions on the quality of selected essential oils. Food Res. Int. 2012, 46, 341-353. [CrossRef] 
45. Farahbakhsh, J.; Najafian, S.; Hosseinifarahi, M.; Gholipour, S. The effect of time and temperature on shelf life of essential oil composition of Teucrium polium L. Nat. Prod. Res. 2020, 1-5. [CrossRef]

46. Turek, C.; Stintzing, F.C. Stability of essential oils: A review. Compr. Rev. Food Sci. Food Saf. 2013, 12, 40-53. [CrossRef]

47. Swisher, H.E.; Swisher, L.H. Specialy Citrus Products. In Citrus Science and Technology; Nagy, P.E.S., Shaw, M.K., Veldhuis, M.K., Eds.; The AVI Publishing Co. Inc.: Westport, CT, USA, 1997; Volume 1, p. 301. 